E-Journal of Tourism Vol.8. No.2. (2021): 184-196

\title{
Green Hotel Concept and Practices in Indonesia
}

\author{
Nining Yuniati* \\ Sekolah Tinggi Pariwisata Ambarrukmo Yogyakarta, Indonesia \\ *Corresponding Author: niningyuniati@gmail.com \\ DOI: https://doi.org/10.24922/eot.v8i2.76346
}

\section{Article Info}

Submitted:

August $1^{\text {st }} 2021$.

Accepted:

September $17^{\text {th }} 2021$.

Published:

September $30^{\text {th }} 2021$

\begin{abstract}
The term of green hotel is still less popular in the community, tourists and even tourism practitioners, as well as many people who do not understand the definition and practice. In Indonesia, green hotels remain an important concern for the government and the private sector regarding the contribution to environmental preservation and reducing the impact of global warming. The application of the green hotel concept still raises pros and cons due to a number of burdensome requirements for business actors. They mostly assume green hotel is a burden and will reduce the comfort of hotel guests. Eventhough in terms of tourists side many of them need green hotel, but in fact not all travelers understand about the green hotel, especially in Indonesia. This paper examines a number of green hotel empirical concepts and facts that have been conducted in various countries and then compares with Indonesia. The case in Yogyakarta is an example on how tourists have not fully understood the concept of green hotels
\end{abstract}

Keywords: Green Hotel, Environmental, Tourist, Guest

\section{INTRODUCTION}

Over the last few years the awareness of environmentally friendly development has continued to grow (Chan \& Chan, 2013). Green Hotel, also well-known as an environmentally friendly hotel, is becoming increasingly recognized by consumers. The popularity of green hotels cannot be separated from the spotlight of the increasing environmental impact caused by tourism activities, containing hotels that include: leakage from community income, pollution, environmental degradation, labor problems, overbuilding, energy use, over use of non durable goods, waste disposal that affects water, soil, and air pollution (Graci \& Dodds, 2008; Sonya Graci \& Kuehnel, 2011).

http://ojs.unud.ac.id/index.php/eot
In line with the issue of global warming, various media then publishing the impact of global warming. The community then start recognizing the importance of green management that is defined as processes and practices within an organization by reducing, eliminating, and preventing negative environmental impacts on all activities undertaken. (Akehurst, Afonso, \& Goncalves, 2012; Wolok, 2019) Later, in its development this condition lead to the era of 'New Tourism' which stimulating the green consumers in 1990s that consumers are increasingly aware of the environmental impact of understanding and embrace enviromentalism ideology and then this ideology began to spread throughout the world (Nor Azila Mohd Noor, Haniza Shaari, \& Kumar, 2014). In this context consumers 
tend to start choosing eco-friendly products including in the use of accommodation or hotels.

In his research on The International Hotel Environment Initiative and Accor, Mensah (2014) stated that $90 \%$ of hotel guests prefer staying in hotels whose environmental concerns. Other studies conducted by JD Power \& Associate 2007 "North America Hotel Guest Satisfaction Study" indicates that $75 \%$ of guests are eager to involve in the hotel's environmentally friendly initiative activities (Butler, 2008). Meanwhile a survey held by Penny (2007) to a number of hotel managers in Macau found that $65 \%$ of respondents believe that well-managed green management can contribute toward hotel imaging and its competitiveness.

Indeed, based on the above facts and data are enough to describe the concept of the Green hotel and the importance for the dynamics of tourism trends forward. $\mathrm{Ne}-$ vertheless, the green hotel even though often its shape is a luxury hotel but usually identical with 'less comfortable'. Consumers are sometimes unconcerned in ecolabel products that seem expensive and unattractive especially when correlated to non-eco-label products (Johri \& Sahasakmontri, 2016). Previous opinions from Manaktola and Jauhari (2007), said that in general consumers will not be willing to pay premium for eco-label products.

The practice of Green Hotel in Indonesia has not been so famous since the criteria and the definition of green hotel itself is still not widely known and recognized by the hotel industry players in general. Still, the trend towards the implementation of the green practices of the hotel has actually been felt by all the people, especially the guests. It's just the opinion of pros and contra about green hotels that connotes costly in operations is often a factor inhibiting practice in the field.

\section{Research Objectives}

The purpose of this research are review and do an assement to people i.e the tourists on how the green hotel has been implemented in Indonesia. A simple case study was conducted to confirm the perceptions of both foreign and domestic tourists regarding the practice of green hotels. This case study was conducted in Yogyakarta, one of the most popular tourist destinations in Indonesia.

\section{LITERATURE REVIEW}

The growing of environment awareness and environmentally friendly practices for hotel business managers have driven to a number of certification bodies in various regions of the world aimed at improving the implementation of green hotel practices and other environmentally friendly businesses. For instance, the United States has Leadership in Energy and Enviromental Design (LEED) \& Energy Star Designation; US Green Building Council (USGBC) then the Green Globe and Eco Management and Adult Scheme (EMAS) indexs developed by WTTC (World Travel and Tourism Council), IHEI (International Hotel Enviromental Initiative) in UK, up to international-class professional organizations have participated in promoting the implementation of environmentally friendly hotels such as the UNEP (United National Enviromental Program), the WTO (World Tourism Organization), WWF (World Wildlife Fund), and Green Star Rating System developed by the Australian Building Council.

Hotel is the main component of a tourist destination (Gunn, 2002). Hotel is a temporary stopover for tourists, including room service and food and beverage service, the most important thing of a hotel product is human resource in the form of services (Perera \& Pushpanathan, 2015). In other word the hotel can be regarded as a tourist attraction, because the main product 
of the hotel in the form of its services play a role in determining the whole tourist experience, so it can be classified as a tourist attraction. In addition, tourists who visit the hotel not only staying, but also do various activities such as recreation-relaxation, culinary, shopping to business and education activities.

Independently hotels can be said having no significant impact on the environment, but in certain accumulations the hotel greatly affects the use of resources such as water, energy (electricity, fuel) and environmental impacts from waste (Baker, Davis, \& Weaver, 2014; Jaiswal \& Kant, 2017). Some of the hotel industry's motivations to switch to sustainable management of sustainable management include: competitiveness, customer loyalty, labor retention, recognition and award, policy / political compromise, risk management, and enhancing the company's brand value (Sonya Graci \& Kuehnel, 2011). Moreover, there are many ways that the hotel is applied in implementing this policy such as the use of energy-efficient lamps, the use of safe detergents, water-efficient showers, local production, green installations, and solar heaters that ultimately gain in some savings and prevention efforts environmental pollution (Rahman, 2017).

The term of green hotel or green lodging according to (Nadia Tszentke, David Kirn, \& Lynch, 2014) is a hotel business associated with 5 (five) stages of hotel life cycle those are planning, construction, operation, maintenance or renovation - shorthand for being environmentally responsible so as to minimize environmental impacts in purchasing, operations and plan management. According to the Green Hotel Association (2018), it has a definition as an eco-friendly hotel where its management is very concerned with the use of clean water, energy use and use, and efforts to reduce waste and other forms of savings in order to maintain environmental sustainability.

http://ojs.unud.ac.id/index.php/eot
Based on the definition of the hotel and also some of the experts above, Green Hotel or can be mentioned as an environmentally friendly hotel is a responsible accommodation or accommodation services by following green living practices. To attain this status of the hotel must be certified by an independent third party or by the country where the hotel is located. As for the criteria used may vary which in essence is how the hotel is able to maintain the surrounding environment.

Furthermore, Sonya Graci and Kuehnel (2011) notes from various studies around the world that through the concept of green hotel at least obtained savings in the use of energy and water up to $20 \%$, garbage reduction up to $15 \%$, improve the quality of the surrounding environment, and increase employee motivation.

Green hotels, not only have the concept of keeping water conservation, reducing energy use, and reducing solid waste production, but more widely contain contributing to the environment, maintaining and developing the surrounding culture, and taking an active role in the development of the regional economic community. The term "green hotel" is pictured as a hotel that is committed to environmental sustainability as efficiently as possible in using of energy, water and materials related to service quality.

Based on the above assumptions, it is quite clear that the green hotel is a manifestation of the increasing awareness of environmental sustainability, especially in the hospitality industry. The concept of green hotel itself is actually part of green tourism product, the chain of sustainable tourism development which then rolled out in various eco-friendly concepts such as green management, green building, green tourism and other green trends.

The criteria used in assessing green hotels in Indonesia should cover at least 10 criteria : land use, energy use, water con- 
servation, environmentally friendly materials, air quality, building governance (waste management), green purchasing, hotel management, food management and corporate social responsibility (CSR) (Auliandri \& Angraeny, 2017; Kemenpar, 2013). The assessment refers to ASEAN Green Hotel Standard (NTOs, 2012), which is the concept of human resource development, waste treatment, energy efficiency, water use efficiency, air quality management, sound pollution management, water-used management and handling, management of handling toxic chemical waste disposal.

The green revolution practice, one of which is applied through the eco-friendly hotel policy in the US, is introduced with the concept of eco-labeling (this concept has been started in Europe since 1985, it is a logo showing that the hotel practices environmentally friendly management), certification conducted by independent institutions, and award for successful (Sharma, 2011). Even later in its development this revolution led to the association Green Hotel Association which is one of the international professional association institutions (www.greenhotels.com).

According to Sharma (2011) just because of some environmental problems the need of green hotels is growing day by day and they are becoming the heart of the tourism industry. The Tourist and hotel guests are now a days more concerned for environmental issues and environmentally friendly hotels in their accommodation choice. This is becoming a standard for luxury hotels. Eco label for hotels in becoming standard and choice for tourists. Without cutting comfort from the menu of guest services, hotels can provide wide range of resources and best practices and innovations technologies which are environment friendly.

A Comparative Study of the Strategies used by leading hotels in US stated that Marriott Hotel is one of the most leading hotels of US is using the strategy

http://ojs.unud.ac.id/index.php/eot for environmental conservation. The Marriott hotel is seek to understand and act on direct and indirect environmental impacts on the business operations. Through this policy the hotel Marriot managed to improve the efficiency of the hotel: 1) Reducing energy and water consumption by $25 \%$ per available room by 2017 , 2) Greening their $\$ 10$ billion supply chain, 3) Expanding their green hotel development tenfold over the next five years, 4) Educating and inspiring associates and guests to support the environment, 5) Addressing environmental challenges through innovative initiatives including rainforest protection and water conservation (Yang, 2017)

Several reviews above it is sufficient to explain the understanding of factors associated with green hotels: Cost saving. According to Robinot and Giannelloni (2015) savings on various expenses is the most important benefit for a hotel. The hotel can maximize efforts efficiently and reduce waste so that it becomes more costeffective than its competitors. For instance, the hotel can reduce energy consumption by $20 \%$ - 40\% without reducing performance.

Competitive advantage. Green hotels serve a competitive edge as leaders in the industry. All this time, the operation of eco-friendly hotels is a key requirement, especially as non-renewable resource costs raise, increasing regulation and increasing demand from environmentally conscious consumers. Therefore, hotels that operate environmentally sound hotels will have a great opportunity to achieve competitive advantage by being "cutting edge" in a globally-developed cycle of sustainability.

Employee performance. It will be able to encourage the emergence of enthusiasm, as well as motivate employees to support sustainable growth goals. In addition, according to Sofia Batista Ferraz, Cláudia Buhamra, Michel Laroche, and Veloso (2017) in his research found that environmentally sound hotel operations have a po- 
sitive impact on job satisfaction, morale, pride and employee loyalty.

Customer satisfaction, motivation and loyalty. They can be obtained because consumers whose environmental awareness values can be fulfilled by the operational demands of environmentally friendly hotels. For 25 years the consumer demand for this has shown an increase. Consumers are increasingly concerned about recycling programs, the efficiency of transport fuel and organic food.

Regulatory compliance. There are numerous state regulations govern the use of waste, water, greenhouse gas emissions and energy use. The hotel should be able to anticipate future regulations and incur fees. With the implementation of green hotels will consistently allow companies to adapt to the rules and avoid the potential costs that arise.

Risk management. Graci and Dodds (2008) discloses that companies that integrate environmental issues in every business decision and reduce their environmental impacts can improve their "position" for better security, thus securing their investment and company reputation.

\section{METHODS}

This research was conducted by combined method of secondary research and field research (survey). Studies conducted by secondary research methodn, that is research which source of data obtained from other side, those are literature library, scientific publication, journal, and also browsing from internet. This type of research is commonly referred to as Desk Research. Research is based purely on the researcher's ability to summarize and analyze data, facts, and existing theories or concepts by way of generalization, correlation, and comparison.

Meanwhile, field research (survey) in question is to conduct research by field survey is to provide questionnaires to hotel users related to the perceptions of the hotel's green practices. The survey method is done as follows: The location of the sampling was conducted in Yogyakarta. The assumption used is Yogyakarta is one of the popular tourist destinations in Indonesia. Yogyakarta currently has a considerable hotel population of 1,160 hotels according to data from Indonesia Hotel and Restaurant Association (IHRA); Target respondents are foreign tourists and domestic tourists who stay in Yogyakarta. The number of respondents surveyed are 120 consisting of domestic tourists and foreign tourists; The method used is simple random sampling which is without regard to the strata in the population and every member of the population has the same opportunity to be sampled. In addition to the survey of this study as well as conducting interviews to tourists for what they chosen; The field research instrument used was a questionnaire with several interview questions and interview guides.

\section{RESULTS AND DISCUSSION}

How far the role of the hospitality industry in the tourism industry, it can be seen from the expenditure of tourists when it comes to a place or a tourist destination. in Indonesia more than $50 \%$ of the money that tourists spend on the hospitality industry (Kemenpar) (2017) in particular accommodation services. Similarly, in countries that show the importance of the hotel's contribution to tourism, a study in the United States in 1969 stated that the money circulating in the hospitality sector was $\$ 7.25$ billion, and by 2013 travel and tourism revenues reached US \$ 1.5 trillion in hotels or accommodation that is the largest contributor with a contribution value of $19 \%$, in addition to food and beverages and transportation (http://selectusa.commerce.gov, 2018). 
The Indonesian Hotel and Restaurant Association (PHRI) said that currently the number of hotel rooms in Indonesia reaches 270,500 units, and will increase by 58,000 next year, the largest in ASEAN. The hotel will become a significant sector contributing to the country's revenue, by 2023 , Indonesia will have as many as 256,000 units of the total 2,400 hotels with an average occupancy rate of $52 \%$. (www. industri.bisnis.com, 2016)

Sinangjoyo (2013) in study of hotels in Yogyakarta mentioned that the implementation of green hotel standards in Yogyakarta in general have implemented environmentally friendly practices. However, there are some obstacles in fact, that is the attitude of less consistent done by hotel staff, lack of awareness of guests, the lack of socialization and the assumption that the implementation of green hotels actually cost expensive. This is like becoming a common problem in the hospitality industry in general. Another aspect that makes the hotel green is still not so desirable is the assumption that the investment in green hotel construction will cost higher than the hotel in general, although with the concept of operational with the environment will save sustainable operational costs (energy and water) the company may increase as energy conservation and environmental conservation is done by the hotel (Sonya Graci \& Kuehnel, 2011).

The assessment of green hotel practices in Indonesia is one of those initiated by Marie E. Pangestu in 2012 when she served as Minister of Tourism and Creative Economy (Menparenkraf) through the $\mathrm{Na}$ tional Green Hotel Award scheme, stating that - of the many 4 star hotels and 5 who stood in Indonesia, was not yet understand the concept of Green Hotel. Green Hotel Award 2012 event is the first time in Indonesia and responded less positive by 290 hotels members of the Hotel and Restaurant Association of Indonesia (PHRI). Of

these, only 76 hotels have returned dispatched forms of participation. From those numbers of the 76 hotels, there are only 32 pass the initial verification. Of these only 31 hotels are willing to be visited by the jury as a further assessment stage.

Taken from the assessment of green hotel in Indonesia in 2017 was announced there are 20 best hotels in Indonesia (2017), among which 10 hotels are declared eligible to represent Indonesia in the ASEAN Green Hotel Award 2018. The 10 hotels are Novotel Bangka Hotel \& Convention Center, Novotel Bandung, Hotel Santika Premiere Jogja, Jogja Plaza Hotel, Singgasana Hotel Surabaya, Ayodya Resort Bali, Bali Tropic Resort \& Spa, Novotel Manado Golf Resort \& Convention Center, The Park Lane Jakarta and Eastparc Hotel Yogyakarta. Meanwhile, 10 other hotels listed in the top 20 hotels are Sheraton Lampung Hotel, Novotel Yogyakarta, Batam View Beach Resort, Ramada Bintang Bali Resort, Patra Jasa Semarang Convention Hotel, Aston Bogor Hotel \& Resort, Hotel Pullman Jakarta Central Park, JW Marriot Hotel Jakarta, Puri Bagus Lovina and Kayumanis Nusa Dua Private Villa \& Spa.

The criteria used in the assessment of green hotel awards in Indonesia are 10 things including land use, energy use, water conservation, environmentally friendly materials, air quality, building governance (waste management), green purchasing, hotel management, food management and corporate social responsibility (CSR) (Kemenpar, 2016). Assessment is also conducted on hotel buildings and hotel management system. Comparison of value is, $25 \%$ for building and $75 \%$ for management problem (management). The building in question is the use of environmentally friendly materials and the management in question is to implement an efficient and environmentally friendly system, whether it is about equipment, electricity, waste and other aspects related to environmental im- 
pact risks.

The National Green Hotel Award is a commitment of the government (Ministry of Tourism of the Republic of Indonesia) together with the Green Building Council Indonesia (GBC Indonesia), the Association of Hotel Engineers (ASATHI), other relevant agencies and stakeholders to give appreciation and appreciation to the perpetrators hotel managers who are committed to apply environmentally friendly principles. Hopefully it will be able to be a program that bridges the gap in the debate, discourse and embodiment of the green movement in Indonesia. Government through the Ministry of Tourism also suggests that actually Green Hotel is a duty of the perpetrators of the hotel industry with the reasons: The hotel industry must involve in the dangers of climate change due to global warming by reducing carbon emissions, saving energy, conserving water, and using environmentally friendly materials; Hotels that save energy such as electricity, water, and fuel are apparently aimed at saving on hotel operating expenses; Demands from the public that business actors participate in energy saving and environmental awareness.

Currently (2016) the government has dismantled a guidance and guidance of green hotel implementation (www.kemenpar.go.id) which is the implication of hotel green awards event held 2 (two) years to the hotel industry in Indonesia. The drafting of the 2016 "Green Hotel" implementation guideline is to encourage the wider community to improve understanding for the wider community (this is not limited to the hoteliers' only societies) to climate change adaptation. As well as spurring them to increase adaptation capacity to climate change, particularly in the hospitality industry sector, as well as contribute to the effort and ease of future implementation plans for the reduction of national greenhouse gas emissions from the building sector. In most current news, mentioned that the competition will be tighter among the hospitality business, especially in the ASEAN region. This has then, led to the creation of environmentally-friendly hotel standards or "Green Hotel Standard" in the ASEAN region.

Instead of the practice of green hotels in large-scale, star hotels, or chains, in Indonesia there is also the concept of ecofriendly hotel whose base is the design and management concept that blends with nature, and conservation aspects that remain the top priority, Ecolodge or Eco-Hotel, or Eco-Friendly Hotel. The meaning of the three terms is the same connotation, according to the dictionary of Oxford means that lodging with hotel facilities (cottage ecotourism) is designed in such a way that minimal negative impact on the surrounding environment, usually built together with the natural environment (www.ecotourism. org, 2012). The concept and criteria of this ecolodge is almost the same as the green hotel.

In the International Ecolodge Guideline published by The International Ecotourism Society (TIES) a world-class organization concerned with ecotourism, it defines ecolodge or eco-friendly hotel concepts including participating in environmental conservation both natural and cultural, contextual with the environment, using water with no excessive, involving the local communities and providing educative values to both employees and tourists

The number of ecolodge in Indonesia currently more than 50 units, among others: Lodges Ekologica, Portibi Farm, in Cicurug; The Pinewood Lodge and Organic Farm, in Cisarua; Kaliandra Eco resort \& Farm (East Java); Greenhost Boutique Hotel and Rumah Turi (Yogyakarta); Ecoguesthouse (Solo); Samboja Lodge (East Kalimantan); The Kelimutu Crater Ecolodge and; Puri Lumbung Cottages in Munduk Village (North Bali); Taman Sari Bali in

e-ISSN 2407-392X. p-ISSN 2541-0857 
Pemuteran (Balibarat); Saribuana Ecolodge in Batakaru Mountain (Tabanan); Bali Ecostay at Kanciana Village (Tabanan); Bambu Indah Eco Luxury Boutique Hotel, Ubud; Amber House Bamboo pavilions on Gili Meno Island (NTB); Eco Divers Resort Lembeh (North Sulawesi); Kadidiri Paradise Dive resort (Togian Island); Wakatobi Dive Resort is located in Southeast Sulawesi in the Marine Reserve area; Ecovillage Silimalombudi Lake Toba (Samosir Island).

Those number of ecolodge above shows that the concept of green hotel is slightly different from the concept of green hotel as applied to star hotels. In other words, the practice of green hotel in Indonesia is divided into two groups: star hotel group and ecolodge or eco-hotel. Government in Indonesia itself is more concerned about the application of green hotel standards that are destined for urban hotels which are generally distinguished by the term star hotels and non-stars. Meanwhile, ecolodge or eco hotels get more attention from foreign media or other international appreciation.

For instance, the appreciation of ecofriendly hotels obtained by Nihi Sumba or popularly known as Nihiwatu is a resort located on Sumba Island, West Sumbar, East Nusa Tenggara This resort is awarded as the best hotel in the world. The award is given by Travel + Leisure which results are obtained based on a survey of Travel + Leisure readers. Nihiwatu got a score of 98.35 and is in position number one of 100 list of the best hotels in the world. Although rated as a newcomer, Nihiwatu beat 99 other hotels on the list to beat world-class eco-hotels such as Spectator (United States), Huka Lodge (New Zealand), Southern Ocean Lodge (Australia), Montage Kpalua Bay (United States), The Lodge Glendorn Bradford (United States), The Willcox (United States), Casa Gangotena (Ecuador), Twin Farms (United States), and
The Singular Patagonia (Chile). Instead of beautiful location, world-class facilities, Nihi Sumba Island is well-liked for its variety of projects involving resort guests to help local communities through the Sumba Foundation. Such as the manufacture of clean water sources, health clinics, child nutrition improvement, and education of school age children.

Generally, the practice of green hotel in Indonesia is quite good, proved by the increasing attention of the public, government and industry to take an active role in environmentally friendly tourism activities. However, in line with the increasing tourist visits, where hotels become an important part of the activities of tourists should be the hotel should get special attention. This is mainly the impact it has on the long term. The issue of global warming is one of the responsibilities of the tourism sector, especially the hotels to participate in helping to create a sustainable and sustainable environment.

How far the role of the hospitality industry in the tourism industry can be seen from the expenditure of tourists when it comes to a place or a tourist destination. In Indonesia more than $50 \%$ of the money spent by tourists is spent on hotels or accommodation and the number of hotel rooms in Indonesia is the largest in ASEAN. The hotel will become a significant sector contributing to state revenue, up to the year 2023 with an average occupancy rate of $52 \%$.

Various forms of business need to be done to minimize the occurrence of global warming through the steps implemented through the movement "Green" to the hotel business actors who are committed to apply the principles of environmentally friendly through water savings program, energy savings, the use of environmentally friendly materials and reduce solid waste. The wide of Indonesian territory with unequal conditions in various regions, quite complica- 
te the integration effort in implementing Green Hotel policies in the same level in various regions. There are areas that may have been very aware of the implementation of green hotels such as Bali, Jakarta, but certainly many other areas that have not been able to karen various factors.

As a sharpening in this analysis, referring to perceptions and also the practice of green hotels has also conducted a simple survey of 120 respondents of foreign tourists and domestic tourists who are in Yogyakarta. The results of this survey generated in a number of opinions as Table 1:

Table 1 explains that of 57 (48\%) of foreign tourist respondents and $63(52 \%)$ of domestic tourists respondents obtained information that: Most foreign tourists (65\%) have known Green Hotel and 35\% do not know; Most Domestic tourists (78\%) are not familiar with Green Hotel, and only $22 \%$ know about green hotels; Most foreign travelers $(69 \%)$ want to use green accommodation and $31 \%$ tend not to want to use environmentally friendly accommodation (green hotels); Most domestic tourists $(51 \%)$ say 'do not know' or can be interpreted hesitantly when asked about the desire to use environmentally friendly accommodation, $37 \%$ are unwilling, and $12 \%$ want to use environmentally friendly accommodation.

The fact above shows that foreign tourists more understand about the green hotel. From the results of a number of interviews conducted by most foreign tourists have ever stayed in a number of hotels labeled 'green hotel' so it can quite feel what kind of service obtained when using the hotel. While most of domestic tourists who do not know about the green hotel, because in general they cannot distinguish the real service hotel is labeled 'green hotel' with the non-green ones.

In a further statement, generaly foreign tourists are more motivated to use eco-friendly hotels as accommodation options. Their awareness of the importance of preserving the environment and maintaining the negative impact of hotels is part of the basis why eco-friendly hotels are more mainstream. Meantime, domestic tourists are more likely to say 'do not know' as a result of the lack of understanding of the green hotel and all its aspects that tend not to have a firm argument in determining the accommodation to be used. Some other tourist statements related to the understanding of green hotel can be observed in table 2.

Table 2 explains that: Both foreign tourists $(90 \%)$ and Domestic tourists $(70 \%)$ agree if the hotel implements environmentally friendly management, so that do not want $10 \%$ for foreign tourists and $30 \%$ for domestic tourists; The majority of foreign tourists $(71 \%)$ understand that hotels can impact on environmental pollution and Table 1. Tourist Opinion About Green Hotel Practice in Yogyakarta (part 1)

\begin{tabular}{|c|c|c|c|c|c|c|c|}
\hline \multirow[t]{2}{*}{$\begin{array}{l}\text { Group of } \\
\text { respondent }\end{array}$} & $\begin{array}{l}\text { Number of } \\
\text { respondent }\end{array}$ & Percentage & $\begin{array}{r}\text { Responc } \\
\text { Do you } \\
\text { gre }\end{array}$ & $\begin{array}{l}\text { Opinion } \\
\text { w about } \\
\text { otel }\end{array}$ & $\begin{array}{l}\text { Do yo } \\
\text { friend }\end{array}$ & $\begin{array}{l}\text { want tc } \\
\text { accom }\end{array}$ & $\begin{array}{l}\text { dse eco- } \\
\text { lodation }\end{array}$ \\
\hline & & & Yes & No & Yes & No & $\begin{array}{l}\text { Do not } \\
\text { know }\end{array}$ \\
\hline $\begin{array}{l}\text { Foreign } \\
\text { Tourist }\end{array}$ & 57 & $48 \%$ & $65 \%$ & $35 \%$ & $69 \%$ & $31 \%$ & \\
\hline $\begin{array}{l}\text { Domestic } \\
\text { Tourist }\end{array}$ & 63 & $52 \%$ & $22 \%$ & $78 \%$ & $12 \%$ & $37 \%$ & $51 \%$ \\
\hline Total & 120 & $100 \%$ & & & & & \\
\hline
\end{tabular}

Noted: Data taken by research at 2019

http://ojs.unud.ac.id/index.php/eot 
Table 2. Tourist Opinion About Green Hotel Practice in Yogyakarta (part 2)

\begin{tabular}{|c|c|c|c|c|c|c|c|c|c|}
\hline \multirow{3}{*}{$\begin{array}{l}\text { Group of } \\
\text { respon- } \\
\text { dent }\end{array}$} & \multicolumn{9}{|c|}{ Respondent Opinion } \\
\hline & \multicolumn{3}{|c|}{$\begin{array}{l}\text { Do you agree if the hotel } \\
\text { must apply environmental- } \\
\text { ly friendly management? }\end{array}$} & \multicolumn{3}{|c|}{$\begin{array}{l}\text { Do you know that } \\
\text { the hotel play a role } \\
\text { in environmental } \\
\text { pollution? }\end{array}$} & \multicolumn{3}{|c|}{$\begin{array}{l}\text { In your opinion, how } \\
\text { is the practice of Green } \\
\text { Hotel in Yogyakarta? }\end{array}$} \\
\hline & Agree & $\begin{array}{l}\text { Dis- } \\
\text { agree }\end{array}$ & Neutral & Yes & No & $\begin{array}{l}\text { Do not } \\
\text { know }\end{array}$ & Good & Enough & $\begin{array}{l}\text { Not } \\
\text { Good }\end{array}$ \\
\hline $\begin{array}{l}\text { Foreign } \\
\text { Tourist }\end{array}$ & $90 \%$ & $0 \%$ & $10 \%$ & $71 \%$ & $21 \%$ & $8 \%$ & $40 \%$ & $25 \%$ & $35 \%$ \\
\hline $\begin{array}{l}\text { Domes- } \\
\text { tic Tour- } \\
\text { ist }\end{array}$ & $70 \%$ & $0 \%$ & $30 \%$ & $28 \%$ & $57 \%$ & $15 \%$ & $20 \%$ & $58 \%$ & $22 \%$ \\
\hline
\end{tabular}

$21 \%$ do not understand, and $8 \%$ not knowing; The majority of domestic tourists $(57 \%)$ do not understand that hotels can impact on environmental pollution, $28 \%$ know, and $15 \%$ doubt that hotels can impact on environmental pollution; Most Foreign Tourists $(40 \%)$ rated that green hotel practices in Yogyakarta are rated Good, $25 \%$ rate enough, and 35\% rate less; Most Domestic Travelers (58\%) assessed that the green hotel practices in Yogyakarta were rated enough, 20\% rated Good, and 22\% rated less.

The fact above explains that foreign tourists are more appreciative and understand about the concept of green hotels, while domestic tourists have the desire or motivation to support the management of environmentally friendly hotels. The background and experience of hotel green accommodation plays an important role in the awareness of tourists on the green values of hotels. Foreign tourists who have more experience compared to domestic tourists tend to be easier to receive while domestic tourists are still hesitant due to lack of experience and understanding of green hotels.

Based on the above results of the survey clearly shows how the difference of respondents opinion of foreign tourists and domestic tourists. It is clear that do- mestic tourists still do not quite understand about the green hotel, while foreign tourists have a better understanding. Factors such as background experience, the number of references to accommodation services that have been used become the basis for the emergence of these opinions.

\section{CONCLUSION}

Green Hotel practice in Indonesia cannot been thoroughly accepted yet, but it can be said that there is a tendency for hotel managers to continue to practice the concept of Green Hotel in real terms. Not only include star hotels but also began to expand in non-star hotels, including boutique hotels such as ecolodge. Various obstacles such as perceptions and procedures about green hotels identical with high costhigh maintenance, support and government participation through a policy that has not been optimal, and understanding of green hotel procedures are things that are part of the constraints of green hotel practices in Indonesia. Currently (2016) the Government through the Ministry of Tourism has launched a blend of green hotel which is expected to be a guide for hotels in implementing green hotel practices. Nevertheless, what has been pursued by the government through regular awards organized by 
the annual National Green Hotel Award is one of the government's strategic steps to support the green hotel implementation campaign in Indonesia. Tourist trends that show a tendency to care more about the environment and are aware of the importance of green products and eco - labels are another driving factor that will further enhance the spread of green hotel practices in Indonesia.

The tendency to use hotels with green hotel concept, from tourist side is also high, it's just that tourists still not fully understand what kind of green concept hotel. Foreign tourists more understand and able to accept environmentally friendly hotels, while domestic tourists tend to be still dubious and do not understand how the concept of green hotels. The role of the government and the hospitality industry in educating guests about green hotels is needed to increase the awareness of tourists how to live in a green hotel. Hotels also need to maintain the comfort of tourists even if the hotel implements environmentally friendly policies.

The efforts that have been pursued by the government through regular awards organized annually National Green Hotel Award is one of the government's strategic steps in order to support the green hotel implementation campaign in Indonesia. Future tourist trends that show an increasing tendency to care about the environment and are aware of the importance of green products and eco-labels are another driving factor that will further enhance the spread of green hotel practices in Indonesia and possibly in other countries as well.

This research has not fully reveal about the implementation and practice of green hotel in Indonesia. The hotel green terminology can be of great significance, which later can be developed in further studies of how it is practiced in hotels in primary destinations in Indonesia as well as in other countries, building criteria and green environment of the hotel, services performed by hotel-based hotels environmentally friendly management and so forth.

\section{REFERENCES}

(Kemenpar), K. P. (2017). Neraca Satelit Pariwisat Nasional (NESPARNAS). Jakarta: Kementerian pariwisata.

Akehurst, G., Afonso, C., \& Goncalves, H. M. (2012). Re-examining Green Purchase Behaviour and The Green Consumer Profile: New Evidences Management Decision, 50(5), 972-988. doi:https://www.doi. org/10.1108/00251741211227726

Association, G. H. (2018). Why Should Be Green? Retrieved from http://www. greenhotels.com/

Auliandri, T. A., \& Angraeny, R. (2017). The Implementation of Green Hotel Management Standard in Majapahit Hotel Indonesia. International Journal of Organizational Innovation, 9(3), 45-62.

Baker, M. A., Davis, E. A., \& Weaver, P. A. (2014). Eco-friendly Attitudes, Barriers to Participation, and Differences in Behavior at Green Hotels. Sustainability and Marketing Cornell Hospitality Quarterely, 55(1), 89-99. doi:https://www.doi. org/10.1177/1938965513504483

Chan, X., \& Chan, K. (2013). Perception of Green Hotels Among Tourist in Hong Kong : An Exploratory Research,. Service Marketing Quarterly, 34(1), 339352. doi:https://www.doi.org/10.1080/ 15332969.2013.827069

Graci, S., \& Dodds, R. (2008). Why Go Green ? The Business Case For Environemtal Commitmen in The Canadian Hotel Industry Anatolia : An International Journal of Tourism and e-ISSN 2407-392X. p-ISSN 2541-0857 
Hospitality Research, 19(2), 251 270. doi:https://doi.org/10.1080/1303 2917.2008.9687072

Gunn, C. A. (2002). Tourism Planning : Basic, Concept, Cases (4th ed.). Routledge: Psychology Press

http://selectusa.commerce.gov.

Retrieved from http://selectusa.commerce.gov

Jaiswal, D., \& Kant, R. (2017). Green purchasing behaviour: A conceptual framework and empirical investigation of Indian consumers. Journal of Retailing and Consumer Services, 41, 60-69. doi:https://doi.org/10.1016/j. jretconser.2017.11.008

Johri, L. M., \& Sahasakmontri, K. (2016). Green marketing of cosmetics and toiletries in Thailand. Journal of Consumer Marketing, 15(3), 265-281. doi:http://dx.doi. org/10.1108/07363769810219134

Kemenpar. (2013). Green Hotel Award Menjadi Nilai Tambah Standar Pelayanan Hotel [Press release]. Retrieved from http://kemenpar.go.id/asp/detil. asp? $\mathrm{c}=16 \& \mathrm{id}=650$

Kemenpar. (2016). Panduan dan Pedoman Pelaksanaan Green Hotel di Indonesia

Manaktola, K., \& Jauhari, V. (2007). Exploring cosumer attitude, and behaviour towards green practices in the lodging industry in India. Journal of Contemporary Hospitality Management, 15(5). doi:https://www.doi. org/10.1108/09596110710757534

Mensah, I. (2014). Different Shades of Green : Environmental Management in Hotels in Accra. International Journal of Tourism Research, 16, 450-461. doi:https://www.doi.org/10.1002/ jtr.1939

Nadia Tszentke, David Kirn, \& Lynch, http://ojs.unud.ac.id/index.php/eot
P. A. (2014). Reason Going Green in Service Accomodation Establishment International Journal of Contemporary Hospitality Management, 1(16), 2. doi:http://www.doi. org/10.1108/09596110410520007

Nor Azila Mohd Noor, Haniza Shaari, \& Kumar, D. (2014). Exploring Tourists Intention to Stay At Green Hotel : The Influence of Environmental Attituded and Hotel Attributes. A Multidisciplinary Journal of Global Macro Trends, 3(7).

NTOs, A. (2012). ASEAN Green Hotel Standard.

Penny, W. Y. K. (2007). The use of environmental management as a facilities management tool in the Macao hotel sector. Facilities, 25(7/8), 286-295. doi: https://doi. org/10.1108/02632770710753325

Perera, H. L. N., \& Pushpanathan, A. (2015). Green Marketing Practices and Customer Satisfaction: A Study of Hotels Industry in Wennappuwa Divisional Secretariat Paper presented at the The 7th Tourism Outlook Conference/Tropical Tourism Outlook Conference, 8-10 August 2014, Dambulla - Kandalama, Sri Lanka http://geog. nau.edu/igust/srilanka2014/ (Copyright: CC-BY-NC-ND) Srin Lanka.

Rahman, M. (2017). The Influencing Factors of Eco-Friendly Products towards Customer Satisfaction: A Study in Bangladesh The SIJ Transaction on Industrial, Financial \& Business Management (IFBM), 5(4).

Robinot, E., \& Giannelloni, J. L. (2015). Do hotels' "green" attributes contribute to customer satisfaction? Journal of Services Marketing, 24(2), 157-169. doi:http://dx.doi. org/10.1108/08876041011031127

e-ISSN 2407-392X. p-ISSN 2541-0857 
Sharma, R. S. a. S. (2011). Hotel Industry Embrace Green Revolution Accross The Globe. International Transactuon in Applied Sciences, Vol 3 (No 3 ), 363-380.

Sinangjoyo, N. J. (2013). Green Hotel Sebagai Daya Saing Suatu Destinasi (Studi Kasus Pada Industri Hotel Berbintang di Wilayah Yogyakarta). Jurnal Nasional Pariwisata, 5(No 2), 83 - 95.

Sofia Batista Ferraz, Cláudia Buhamra, Michel Laroche, \& Veloso, A. R. (2017). Green Products : A CrossCultural Study of Attitude, Intention and Purchase Behavior. RAM (Mackenzie Management Review) Sao Paulo, 18(5), 12-38 doi:https://www.doi. org/10.1590/1678-6971201

Sonya Graci, \& Kuehnel, J. (2011). How to Increase Your Bottom Line by Going
Green Retrieved from Canada: http:// green.hotelscombined.com/Pages/ MainGreen/Downloads/responsibletraveler-guide.pdf

Wolok, T. (2019). Analysis of The Effect of Green Marketing on Consumer Purchasing Decisions on The Body Shop Gorontalo Product. International Journal of Applied Business and International Management, 4(2). doi:ttps:// doi.org/10.32535/ijabim.v4i2.569

www.ecotourism.org. (2012). International Ecolodge Guideline yang diterbitkan oleh The Internasoinal Ecotourism Society (TIES) Retrieved from https:// www.ecotourism.org/ecolodges

Yang, Y. C. (2017). Consumer Behaviour Towards Green Products. Journal of Economics, Business and Management, 5 (4 ). doi:https://www.doi. org./10.18178/joebm.2017.5.4.505 